\title{
The performance and profitability of plantain/clover pasture mixtures in East Coast farming systems
}

\author{
Paul D. MUIR ${ }^{1 *}$, Beverley C. THOMSON ${ }^{1}$, Noel B. SMITH ${ }^{1}$, Kathleen R. WARD ${ }^{1}$, \\ Lochie MACGILLIVRAY ${ }^{2}$ and Malcolm J. MACFARLANE ${ }^{3}$ \\ ${ }^{1}$ On-Farm Research, PO Box 1142, Hastings, New Zealand \\ ${ }^{2}$ AgFirst Hastings, PO Box 1261, Hastings, New Zealand \\ ${ }^{3}$ Deceased \\ *Corresponding author: paul@on-farm.co.nz
}

\begin{abstract}
Yield and animal performance data from plantain/clover and resident ryegrass-based pastures were collected over several years from six properties on the East Coast of the North Island. This information was used in a FARMAX ${ }^{\circledR}$ model developed for a hypothetical farm based on data collected by the Beef + Lamb Economic Service. The hypothetical farm was 495 ha with 50 ha of flats used for silage and/or winter forage crop. The base model had a gross margin of $\$ 703 /$ ha. The 50-ha flat block was modelled as if in a plantain rotation with two thirds in plantain and one third in annual ryegrass each year. The higher yields and better-quality feed on the plantain block improved animal performance and carcass weights. Early mating of one-year ewes for feeding on plantain provided a very high-returning enterprise. More ewes and lambs were killed early at heavier carcass weights with a premium before the onset of summer-dry conditions. This became a force multiplier across the entire farm as more feed was available for other stock and lamb carcass weights increased across the farm. Highest returns were generated by using the extra quality feed to increase ewe liveweights by $8 \mathrm{~kg}$. Whilst ewe numbers had to be decreased, this was more than compensated for by the higher lambing percentage and greater number of lambs from mated hoggets. The combined effect was an increase in farm gross margin by around $\$ 200 /$ ha and in farm returns of $\$ 100,000$.
\end{abstract}

Keywords: plantain, DM production, animal performance, modelling, profitability

\section{Introduction}

Increasing frequency of droughts on East Coast North Island hill country has led to an interest in more robust farming systems. Often this means maximising farm production during times when moisture is not limiting (i.e. winter and spring) rather than extending feed production into dry conditions. Plantain (Plantago lanceolata) is an upright perennial herb, which combines well with erect clover species in pasture mixtures that can substantially out-yield ryegrass/clover pasture from winter to early summer in the east coast of the North Island (Macfarlane et al. 2014). Plantain monocultures can lead to superior animal performance compared with ryegrass/clover (Moorhead et al. 2002: Judson, 2009; Kemp et al. 2013), and the combination of plantain with annual or perennial clovers has potential to markedly lift animal growth rates from what is achievable with ryegrass/clover.

To estimate the impacts of using plantain/clover mixtures on farm production and profit in the East Coast of the North Island, the early work of Macfarlane et al. (2014) comparing pasture and animal production on farms in the region was extended to collect a more comprehensive dataset covering more years, climates, topography and soil types. These data were used in a FARMAX ${ }^{\circledR}$ model developed to represent a typical summer-dry, hill-country farm. This paper reports the predicted animal production and profit of the 'base' farm system, and the same system incorporating plantain/clover mixtures under two stock management scenarios.

\section{Materials and Methods}

Dry matter yields and animal performance

A brief description of the methods used in the on-farm component trials is presented below. More details on the general approach are available in Macfarlane et al. (2014).

Dry matter yields (DMY) from plantain (cv 'Tonic') pastures were measured on 6 properties from Gisborne to Wairarapa across a number of years (2011-2015). Properties involved were Te Aute Station (Poukawa district, central Hawke's Bay; contour steep but cultivable), Poporangi Farm (Kereru, central Hawke's Bay; flat), Te Mahanga Station (Poukawa, central Hawke's Bay; flat), Waitai Valley (Wairoa, northern Hawke's Bay; flat), Wairakaia Station (Muriwai, Gisborne; steep but cultivable) and Tokoroa Farm (Ponatahi, Wairarapa; flat). Plantain/clover mixture treatments included various combinations of red clover (Trifolium pratense), white clover (T. repens), Persian clover ( $T$. resupinatum), balansa clover ( $T$. michelianum), arrowleaf clover (T. versiculosum) and 
subterranean clover (T. subterraneum). Control pasture treatments consisted of resident pasture from a nearby paddock with a similar soil type and contour. At each site, between three and five areas were trimmed to 6 $\mathrm{cm}$ height and $0.50 \mathrm{~m}^{2}$ cages placed on the trimmed areas to exclude stock both within the plantain and the resident pasture control sites. At 4- to 6-week intervals, the forage in each cage was cut to $6 \mathrm{~cm}$ and the cage shifted to a new site within the same paddock. The harvested pasture sample was weighed and a $200 \mathrm{~g}$ subsample dried at $80^{\circ} \mathrm{C}$ for 48 hours and the growth rate calculated from the amount of regrowth between cuts.

On-farm measurements of animal performance were carried out with lactating ewes where ewe and lamb performance on plantain/clover were compared with that on ryegrass-based pastures. Measurements were conducted at Tokoroa Farm (in 2015) and Wairakaia Station (2015), plus Tourere (central Hawke's Bay in 2013 and 2014), and Poukawa Research Station (central Hawke's Bay, in 2014 and 2016). In all cases, small flocks of ewes (range $\mathrm{n}=18$ to 181 ) with lambs (mean 165\% of ewe numbers) were set stocked on the control pasture or rotationally grazed on the adjacent plantain/clover pasture from lambing or docking until weaning (mean duration of measurement periods $=71$ days). Exceptions to this general approach occurred at Poukawa in 2014 where ewes reared only single lambs, and at Tokoroa Farm where a further 106 ewes and 135 lambs were added (to the original 124 and 198) to the plantain/clover treatment for the final 27 days before weaning. Ewes and lambs were weighed at the beginning and end of each trial period. Ewe stocking rates during the measurement period were generally higher on the plantain/clover pasture than the control pasture reflecting the greater spring pasture growth rates on the former.

\section{Development of the base model}

The base model was developed using survey data collected by Beef + Lamb NZ's Economic Service from 18 summer-dry, hill-country farms. The model farm represents 975 Class 4 farms on the East Coast of the North Island. The 495-ha hypothetical farm is divided into three blocks. Fifty hectares is flat and used for silage and/or winter crop, while a further 178 ha is classed as easy rolling and 267 ha classed as hill country. Annual DMY of the three blocks is 9340,9120 and $7410 \mathrm{~kg} \mathrm{DM} / \mathrm{ha}$. Typically, of the 50 ha of flats, 8 ha is utilised for winter feed (kale: yield 10 t DM/ ha) followed by rape for summer feed (DMY $5 \mathrm{t} / \mathrm{ha}$ ). A further 20 ha of flats are cut for silage, yielding a total of 54 tonnes DM. The kale and silage are allocated to the cattle enterprise in the base model.

The whole farm produces an average of $8240 \mathrm{~kg} \mathrm{DM} /$ ha of home-grown feed. It carries 2800 breeding ewes and 850 hoggets. Lambing percentage is $123 \%$. No hoggets are mated. Some (49) trade lambs are bought in April at $30 \mathrm{~kg}$ liveweight and finished over July and August to $20.7 \mathrm{~kg}$ carcass weight. Of the 2585 lambs sold, only $8 \%$ are drafted for slaughter at weaning. The remaining lambs are finished through summer to average carcass weights of $16.1 \mathrm{~kg}$. Cattle make up $40 \%$ of the stock units with 90 breeding cows and steers finished at 2.5-3 years of age. Weaner bulls (108) are purchased in summer and autumn and sold at 2.5 years. The base model shows a gross margin of $\$ 347,926$ or $\$ 703 /$ ha.

\section{Assumptions used to incorporate plantain/clover pastures into the model}

- The 50-ha flat block in the base model was assigned to a plantain/clover pasture rotation with annual ryegrass/brassica. Each year, 16.7 ha (a third of the area) is planted in plantain/clover, another third is in its second year of plantain/clover, and a further third is planted in annual ryegrass/brassica to provide the opportunity for weed control. Plantain/clover pastures are only grazed by sheep and have no impact on the cattle policy or returns. Assumptions around yield and animal performance of the plantain/ clover pastures are based on the data collected as described in the previous section, the key ones being as follows: Plantain/clover produces $42 \%$ and $16 \%$ more total DMY in Year 1 and 2, respectively. In Year 1, the seasonal yields of plantain/clover over the base ryegrass/clover pasture in autumn, winter, spring and summer are $-40 \%,+46 \%,+36 \%$, and $+56 \%$ respectively. In Year 2 , the advantages to plantain/clover are $+26 \%,+38 \%,+7 \%$ and $+12 \%$, respectively.

- Incorporating a plantain/clover rotation increases the feed grown on the 50 ha of flats by $1710 \mathrm{~kg} \mathrm{DM} / \mathrm{ha}$ per year.

- An early mated (Feb 22 $2^{\text {nd }}$ ) group of one-year ewes are rotationally grazed on plantain/clover (17 ewes/ ha) between docking and weaning. Lambs grow $18 \%$ faster on plantain pre-weaning and have a $2.3 \%$ higher dressing out percentage (DO\%). Ewes grow $12.4 \%$ faster on plantain/clover and are $8 \mathrm{~kg}$ heavier at weaning. Cull ewes are slaughtered at weaning and have a DO $\%$ of $45.3 \%$.

Cropping costs are as per the Lincoln University Financial Budget Manual (Askin \& Askin 2018). Plantain/clover establishment costs assume direct drilling, slug treatment and an early winter weed spray). Annual insecticide spray costs for plantain moth are included. Ewe and lamb seasonal pricing and wool returns are as per FARMAX ${ }^{\circledR}$ Auto North Island prices for January 2018. 


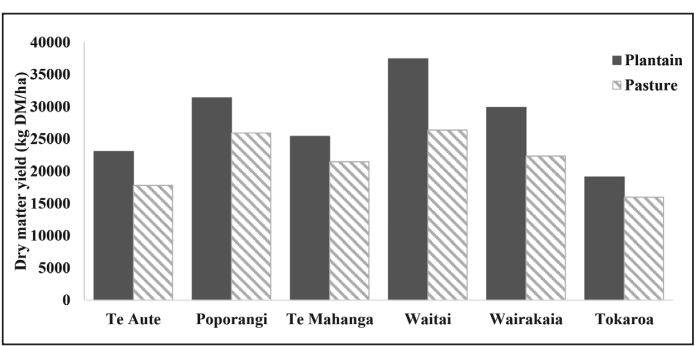

Figure 1 Comparative yields at six East Coast locations and over two years of plantain/clover pastures and resident pastures

In the base model, kale and silage are allocated to the cattle during winter. In the plantain/clover model, cattle are wintered on annual ryegrass and on pasture because winter feed covers are approximately $100 \mathrm{~kg} \mathrm{DM} / \mathrm{ha}$ higher as a result of stock leaving the farm earlier than in the base model.

Whilst a number of scenarios were explored, only two are reported here.

Scenario 1: Simulates a situation where ewe liveweights at mating are maintained at $60 \mathrm{~kg}$ and ewe numbers are held at 2800. Ewe lambs are heavier at weaning and this enables some hogget mating. Early weaning and more feed available enable some trade lambs to be purchased in December and finished in February/March.

Scenario 2: Simulates a situation where the extra feed on the plantain block and the extra feed available post weaning across the whole farm enables an increase in ewe liveweights. In this scenario, ewe mating liveweights stabilise at $68 \mathrm{~kg}$ over time. This results in a higher lambing percentage but a reduction in ewe numbers to match the available winter feed supply. This scenario also enabled some hogget mating and the purchase of trade lambs in December.

\section{Results and Discussion \\ Dry matter yields}

Across all six properties, plantain/clover pastures outyielded permanent ryegrass-based pastures in the first two years after establishment by $28 \%$ (27.7 t DM/ha vs $21.6 \mathrm{t} \mathrm{DM} / \mathrm{ha}$ ). At the higher rainfall Waitai Valley site, plantain/clover pastures produced an additional $11 \mathrm{t} \mathrm{DM} /$ ha over two years whereas at Tokoroa plantain/ clover pastures produced an additional $3.1 \mathrm{t} \mathrm{DM} / \mathrm{ha}$ (Figure 1). The advantage to plantain/clover pastures was $42 \%$ in Year 1 and $16 \%$ in Year 2. In Year 3, only two (Poporangi Farm and Te Mahanga Station) of the six plantain pastures remained and these produced $9 \%$ less DM than the control pastures.

Autumn sowing meant that average DMY was lower for plantain/clover in autumn of Year 1 and this was compounded by a dry autumn on two of the properties.

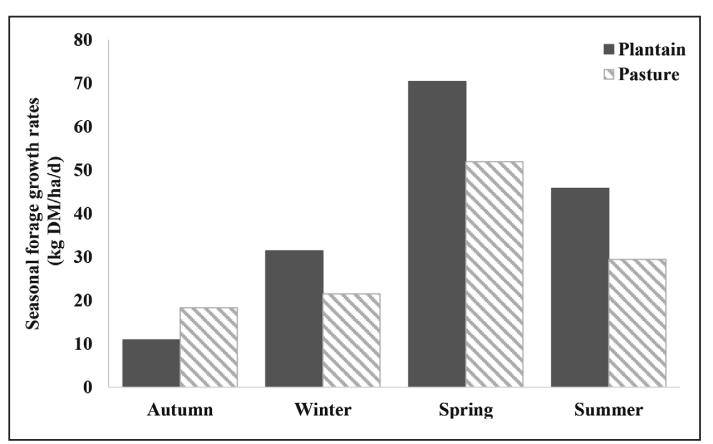

Figure 2 Seasonal yields in Year 1 of plantain/clover and resident pastures on six East Coast locations

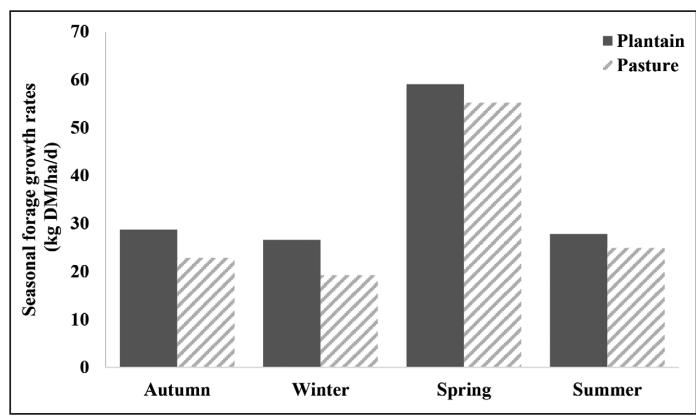

Figure 3 Seasonal yields in Year 2 of plantain/clover and resident pastures on six East Coast locations

Otherwise, seasonal yields over the first two years consistently favoured plantain/clover pastures (Figures 2 and 3). Cranston et al. (2015) suggested that herb/ clover mixes including plantain have negligible winter growth in the Manawatu, yet in this study, average winter growth rates of plantain/clover were $30 \mathrm{~kg} \mathrm{DM} /$ ha/day. This winter growth is a key advantage in East Coast dryland where farm profitability is often dictated by the stocking rate that can be carried through the winter and by the stock that can be finished early to both decrease stocking rate before summer and to take advantage of seasonal premiums available for early slaughter of ewes and lambs.

\section{Animal performance}

Across all measurement sites, the performance of ewes and lambs was higher on plantain/clover pastures than on ryegrass-based pastures. When the results are summarised (Table 1) along with two trials from Canterbury (Judson 2009), ewes grazing plantain/ clover were $76.0 \mathrm{~kg}$ at weaning, whereas ewes off ryegrass-based pastures were only $67.6 \mathrm{~kg}$. Lambs off plantain/clover pastures grew faster (341 vs $289 \mathrm{~g} / \mathrm{d}$; Table 2).

Ewes slaughtered directly off plantain/clover had an average DO of $45.1 \%$ compared with 41.5 for those off ryegrass-based pastures. The corresponding figures for 
lambs slaughtered directly off the ewes were $46.3 \%$ and $43.9 \%$, respectively. The higher DO $\%$ for animals off plantain/clover pasture are due to lower levels of gut contents associated with the faster rumen transit times of high-quality feeds. The combination of better growth rates and a higher $\mathrm{DO} \%$ provides a double-benefit in favour of plantain/clover. A hypothetical lamb with a birthweight of $4.9 \mathrm{~kg}$ growing on plantain/clover pasture at $341 \mathrm{~g} / \mathrm{d}$ to 14 weeks of age and a DO of $46.3 \%$ would have a carcass weight at weaning of 17.7 $\mathrm{kg}$. The same lamb growing at $289 \mathrm{~g} / \mathrm{d}$ on ryegrassbased pasture and with a DO of $43.9 \%$ would have a carcass weight at weaning of $14.6 \mathrm{~kg}$.

\section{Modelling results}

Scenario 1: The increased quantity and quality of feed grown on the plantain/clover rotation block enabled a predicted 590 one-year ewes and their lambs to be mated early and fed on plantain/clover during lactation. This, in turn, enabled the early weaning of these ewes (428 vs 0 in the base model). Of the 811 lambs reared on plantain/clover, the model predicted $87 \%$ (709) could be slaughtered at weaning at carcass weights of $18.6 \mathrm{~kg}$. Early season premiums meant average lamb returns increased to $\$ 5.99 / \mathrm{kg}$ compared with $\$ 5.58 /$ $\mathrm{kg}$ in the base model. Ewe lambs were predicted to be heavier at weaning, enabling 305 of the 850 hoggets to be mated and produce an extra 186 lambs for slaughter. The predicted differences in feed supply allowed the purchase of an additional 110 lambs in April at $27 \mathrm{~kg}$ liveweight which were killed in July and August at a carcass weight of $20.7 \mathrm{~kg}$. Overall, compared to the base model, predicted average carcass weights increased

Table 1 Ewe weaning weights on plantain/clover and ryegrass-based pastures.

\begin{tabular}{|c|c|c|c|}
\hline $\begin{array}{l}\text { Weaning } \\
\text { weight off } \\
\text { plantain } \\
(\mathbf{k g})\end{array}$ & $\begin{array}{l}\text { Weaning } \\
\text { weight off } \\
\text { pasture } \\
(\mathrm{kg})\end{array}$ & $\begin{array}{c}\text { Advantage } \\
\text { to } \\
\text { plantain } \\
\text { (kg) }\end{array}$ & Location \\
\hline 76.6 & 62.5 & +14.1 & $\begin{array}{l}\text { Ceres Research Centre, } \\
\text { Canterbury }(2009)^{1} \mathrm{RG}\end{array}$ \\
\hline 77.2 & 67.7 & +9.5 & $\begin{array}{l}\text { Ceres Research Centre, } \\
\text { Canterbury }(2009)^{1} \text { SS }\end{array}$ \\
\hline 70.5 & 63.0 & +7.5 & Tourere (2013) \\
\hline 77.0 & 72.3 & +4.7 & Poukawa (2014) \\
\hline 79.5 & 73.6 & +5.9 & Tokaroa (2014) \\
\hline 78.0 & 67.0 & +11.0 & Wairakaia (2015) \\
\hline 73.2 & 67.3 & +5.9 & Poukawa (2016) \\
\hline 76.0 & 67.6 & +8.4 & \\
\hline
\end{tabular}

1 Judson et al. (2009). RG = Rotational grazing. SS = Set stocking. Only ewe liveweight change was given in that paper so starting liveweights have been assumed to be $70 \mathrm{~kg}$ for the purposes of this table. from $16.1 \mathrm{~kg}$ to $18.6 \mathrm{~kg}$ and there were an additional 238 lambs slaughtered from hoggets and trade lambs. Early mating, better feeding and early weaning of the one-year ewes meant the cull ewes were slaughtered early at heavier carcass weights. Predicted cull ewe carcass weights were $30.7 \mathrm{~kg}$ (compared to $24.2 \mathrm{~kg}$ in the base model) and early-season premiums meant cull ewe returns increased to $\$ 3.26 / \mathrm{kg}$ (compared to $\$ 3.17$ / $\mathrm{kg}$ in the base model). Total farm revenue increased from $\$ 515,492$ in the base simulation to $\$ 607,630$. Whilst variable costs increased from $\$ 347,916$ to $\$ 421,906$, there was an overall increase of $\$ 73,990$ in the farm gross margin, equating to an additional \$149/ ha across the whole farm (Table 3).

Scenario 2: The extra feed grown on the plantain/ clover rotation block resulted in predicted ewe mating liveweights of $68 \mathrm{~kg}$ compared with $60 \mathrm{~kg}$ in the base scenario. To accommodate this, ewe numbers were decreased from 2800 to 2600 to match winter feed supply. However, the heavier ewe mating weights resulted in an increased lambing percentage from 123\% to $135 \%$ and, compared to the base model, the predicted total lambs produced on farm increased by 625 to 3852 . Slightly fewer one-year ewes were fed on plantain/ clover (532 vs 590 in Scenario 1). Nevertheless, the model predicted that $94 \%$ of lambs $(682 / 725)$ were drafted off plantain/clover at carcass weights of $18.7 \mathrm{~kg}$. More lambs (402 vs 150 in Scenario 1) were also drafted off the heavier pasture fed ewes. Slightly fewer trade lambs (74) were purchased in April than in Scenario 1 and killed at the same carcass weight of $20.7 \mathrm{~kg}$. As in Scenario 1, more and better-quality feed led to heavier lamb carcasses (18.5 $\mathrm{kg}$ overall) and

Table 2 Pre-weaning lamb growth rates on plantain/clover and ryegrass-based pastures.

\begin{tabular}{cccl}
\hline $\begin{array}{c}\text { Lamb } \\
\text { growth } \\
\text { rate on } \\
\text { plantain } \\
(\mathbf{g} / \mathbf{d})\end{array}$ & $\begin{array}{c}\text { Lamb } \\
\text { growth } \\
\text { rate on } \\
\text { pasture } \\
(\mathbf{g} / \mathbf{d})\end{array}$ & $\begin{array}{c}\text { Advantage } \\
\text { to } \\
\text { plantain }\end{array}$ & \multicolumn{1}{c}{ Location } \\
\hline 376 & 296 & +80 & $\begin{array}{l}\text { Ceres Research Centre, } \\
\text { Canterbury (2009) } \mathrm{RG}\end{array}$ \\
346 & 309 & +37 & $\begin{array}{l}\text { Ceres Research Centre, } \\
\text { Canterbury (2009) } \mathrm{SS}\end{array}$ \\
325 & 289 & +36 & Tourere (2013) \\
356 & 306 & +50 & Poukawa (2014) \\
309 & 285 & +24 & Tourere (2014) \\
324 & 313 & +11 & Tokoroa (2014) \\
337 & 255 & +82 & Wairakaia (2015) \\
353 & 259 & +94 & Poukawa (2016) \\
341 & $\mathbf{2 8 9}$ & +52 & \\
\hline
\end{tabular}

${ }^{1}$ Judson et al. (2009). RG = Rotational grazing. SS = Set stocking 
more hoggets (440/850) could be mated. The combination of heavier ewes at mating lead to a higher lambing percentage, which together with hogget mating meant that compared to the base system, the model predicted there would be an additional 421 lambs for sale. Predicted overall carcass weights increased to $18.5 \mathrm{~kg}$, up from $16.1 \mathrm{~kg}$ in the base model. Cull ewe carcass weights were $33.2 \mathrm{~kg}$ and early season premiums meant cull ewe value was $\$ 108.51$ compared to $\$ 77.15$ in the base model. Using plantain/clover to increase ewe liveweights gave the highest returns of the two scenarios that were simulated. Predicted gross farm revenue increased to $\$ 629,977$ and variable expenses increased to $\$ 181,843$. Overall farm gross margin was $\$ 100,218$, equivalent to $\$ 905 /$ ha or $\$ 202 /$ ha more than in the base model.

\section{Conclusions}

Even when used as a two-year crop, plantain/clover pastures and the high animal performance associated with them have the potential to be a game-changer in warmer, drier areas where temperatures permit strong winter and early spring growth of plantain and clover. However, sufficient areas must be planted to allow for an effective grazing rotation. Moreover, a higher level of management is required to monitor pests and diseases and to avoid over-grazing. There are also extra costs involved with plantain/clover pastures including a higher level of management input, more frequent stock shifts, more frequent pasture renovation and higher weed and pest control costs.

Incorporating a plantain/clover rotation into $10 \%$ of the model dryland farm generated higher yields

Table 3 Gross margins for two plantain systems on dryland East Coast hill country

\begin{tabular}{|c|c|c|c|}
\hline & $\begin{array}{l}\text { Base model } \\
60 \mathrm{~kg} \mathrm{ewe}\end{array}$ & $\begin{array}{c}\text { Plantain/clover } \\
\text { Scenario } 1 \\
60 \mathrm{~kg} \text { ewe }\end{array}$ & $\begin{array}{c}\text { Plantain/clover } \\
\text { Scenario } 2 \\
68 \mathrm{~kg} \text { ewe }\end{array}$ \\
\hline Ewes wintered & 2800 & 2800 & 2600 \\
\hline Lambing \% & 123 & 123 & 135 \\
\hline Hoggets mated & 0 & 305 & 440 \\
\hline Early lambing ewes on plantain & 0 & 590 & 532 \\
\hline Lambs bought in & 49 & 110 & 74 \\
\hline Lambs drafted at weaning & 194 & 859 & 1084 \\
\hline Average weaning draft carcass weight $(\mathrm{kg})$ & 15.9 & 18.6 & 18.7 \\
\hline Average lamb growth rate $(\mathrm{g} / \mathrm{d})$ & 130 & 170 & 190 \\
\hline Average carcass weight of own bred lambs (kg) & 16.1 & 19.0 & 18.6 \\
\hline Average carcass weight of purchased lambs $(\mathrm{kg})$ & 20.7 & 20.7 & 20.7 \\
\hline Average carcass weight of all lambs & 16.1 & 18.6 & 18.5 \\
\hline Number of lambs sold & 2621 & 3075 & 3042 \\
\hline Average ewe carcass weight (kg) & 24.2 & 30.7 & 33.2 \\
\hline Value of all cull ewes (\$/ewe) & 73.17 & 92.11 & 108.51 \\
\hline Number of mixed age ewes sold & 588 & 589 & 522 \\
\hline \multicolumn{4}{|l|}{ Financial results $(\$)$} \\
\hline Sheep sales - purchases & 232,347 & 328,163 & 352,682 \\
\hline Wool & 70,285 & 66,606 & 64,434 \\
\hline Beef & 212,860 & 212,860 & 212,860 \\
\hline Total revenue & 515,492 & 607,630 & 629,977 \\
\hline Crop and feed costs & 32,700 & 53,193 & 53,438 \\
\hline Stock costs - animal health/shearing & 57,462 & 55,098 & 50,866 \\
\hline Interest on capital - livestock and feed & 77,414 & 77,433 & 77,539 \\
\hline Total variable expenses & 167,576 & 185,724 & 181,843 \\
\hline Gross margin & 347,916 & 421,906 & 448,134 \\
\hline Difference from base & 0 & 73,990 & 100,218 \\
\hline Gross margin per ha & 703 & 852 & 905 \\
\hline
\end{tabular}


of better-quality feed which enabled better predicted animal growth rates and heavier ewe and lamb carcass weights. Identification and early mating of one-year ewes which are subsequently fed on plantain/clover during lactation has the potential to generate high financial returns. Ewes increase in weight on plantain/ clover, have higher dressing out percentages, are killed at heavier carcass weights and are sold off the farm at a premium price before the onset of summer-dry conditions. This becomes a force multiplier across the rest of the farm because there is more feed available to other stock and lamb carcass weights increase across flock. Ewe lambs are heavier and this enables some hogget mating and lamb numbers increase further.

Both plantain/clover scenarios generated higher predicted farm gross margins. However, using the extra quality feed to increase ewe liveweights from 60 to 68 $\mathrm{kg}$ resulted in the highest gross margins. Whilst ewe numbers were reduced, the higher lambing percentage and greater number of lambs produced from hoggets more than compensated for this. The combined effect was an increase in gross margin of around \$200/ha or $\$ 100,000$ for the enterprise.

It is worth noting that the production results and modelled returns have been achieved within climatic conditions which are winter-warm and summer-dry and which have enabled good winter and early spring growth rates of plantain and clover. These results cannot be extrapolated to wetter and colder areas.

Farmer observations: At several of the on-farm measurement sites, plantain moth (Scopula rubriana) removed plantain in the second summer as the rapid life cycle of the moth means that caterpillar populations can build up rapidly when farmers are not vigilant. All farmers involved identified the need to utilise plantain/ clover pastures with their highest returning sheep enterprises, either hoggets with lambs at foot or ewes with multiples. Two of the farmers in this study identified their cull ewes at pregnancy scanning and then grazed plantain/clover pastures with cull ewes rearing multiple lambs. At weaning, typically $60 \%$ or more of these twin lambs were drafted for slaughter along with all the cull ewes. The plantain/clover pastures were then used for the finishing of remaining lambs. The heavier ewe and lamb weights were a strong contributor to profit and meant that many of the cull ewes were slaughtered well before the pressure comes on for killing space, thus helping de-stock before summer.

\section{ACKNOWLEDGEMENTS}

The monitoring programme was carried out with funding from MPI's Sustainable Farming Fund (Project 11/104 and 401457) Beef + Lamb NZ and the Hawke's Bay Regional Council. Publication of this work was undertaken by programme BLNZT1701 with funding from MBIE, Beef + Lamb NZ, Seed Force and PGGW. The authors would like to acknowledge the farmer groups who oversaw this project (Peter Swinburn, Rob Buddo, Chris Dooney, Richard Lee, Andrew Thomas, Ian Milner, Paul Train and Mark Harris). We are grateful to the farmers who so willingly made their properties available for forage and animal measurements which generated the local data for use in this model: Rob Faulkner, Nigel Tomalin, Jim Spall, David Brownrigg, Pete Swinburn and Dan Nicolson.

\section{REFERENCES}

Askin D, Askin V. (Eds). 2018. Lincoln University Financial Budget Manual. Faculty of Agribusiness and Commerce, Lincoln University, Christchurch, New Zealand.

Cranston LM, Kenyon PR, Morris ST, Kemp PD. 2015. A review of the use of chicory, plantain, red clover and white clover in a sward mix for increased sheep and beef production. Journal of New Zealand Grasslands 77: 89-94.

Judson HG, McAnulty R, Sedcole R. 2009. Evaluation of 'Ceres Tonic' plantain (Plantago lanceolata) as a lactation feed for twin-bearing ewes. Proceedings of the New Zealand Grassland Association 71: 201205.

Kemp PD, Kenyon PR, Morris ST, Somasiri SC. 2013. Plantain (Plantago lanceolata) in herb and legume pastures increases lamb growth relative to perennial ryegrass and white clover pasture. In: Proceedings of the $22^{\text {nd }}$ International Grassland Congress, pp 561562.

Moorhead AJE, Judson HG, Stewart AV. 2002. Liveweight gain of lambs grazing 'Ceres Tonic' plantain (Plantago lanceolata) or perennial ryegrass (Lolium perenne). Proceedings of the New Zealand Society of Animal Production 62: 171-173.

Macfarlane MJ, Thomson BC, Crofoot E, Hamilton G, Ashby H, Muir PD. 2014. Evaluating new forage systems for East Coast dryland. Proceedings of the New Zealand Society of Animal Production 74: 108114. 